\title{
Critical aspects of feed protein evaluation systems for ruminants \\ P. Huhtanen
}

MTT Agrifood Research Finland

FIN-31600 Jokioinen

\begin{abstract}
The current feed protein evaluation systems taking into account the amount of amino acids absorbed from the small intestine are critically reviewed. Especially the differences in the concepts of estimating protein values and limitations of techniques used to estimate parameter values are discussed. Validation of different approaches to estimate the microbial component of metabolizable protein using data from production experiments was conducted. The review is focused on empirical models based on factorial approaches. In the future, the mechanistic models, which can better take into account interactions in the digestive tract and tissue metabolism, should be developed.
\end{abstract}

KEY WORDS: protein evaluation, systems, empirical models, ruminants

\section{INTRODUCTION}

Protein evaluation systems based on crude protein $(\mathrm{CP})$ and digestible $\mathrm{CP}$ have been replaced by systems estimating the amount of amino acids absorbed from the small intestine. A number of new feed protein evaluation systems and their modifications have been published during the last two decades (e.g., Madsen, 1985; Vérité and Peyraud, 1989, AFRC, 1992; Tamminga et al., 1994, Madsen et al., 1995; NRC, 2001). All these systems consider separately the protein requirements of rumen microorganisms and the amount of amino acids available for the host animal metabolism, allowing better predictions of production responses and $\mathrm{N}$ losses to the environment.

Although the novel protein evaluation systems are conceptually similar, they differ in terminology, calculation of microbial protein supply and procedures used

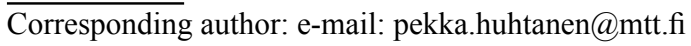


to estimate the parameter values required to calculate the supply of metabolizable protein (MP). The progress in developing feed protein evaluation systems has probably been more limited by difficulties in obtaining meaningful measurements of ruminal $\mathrm{CP}$ degradability and reliable estimates of microbial protein synthesis than by theoretical model concepts. Because microbial protein has a major contribution to the total MP supply, the importance of ruminally undegraded protein (RUP) has been overemphasised at the expense of optimizing microbial protein synthesis (MPS) in the rumen (Beever and Cottrill, 1994). Validation of in situ derived effective protein degradability and consequent MPS against in vivo has been rather limited, mainly due to methodological difficulties and intra- and interlaboratory variation in obtaining reliable reference values for developing alternative techniques. In that respect, it is slightly surprising that data from production studies have not extensively been used for the validation of protein systems. Production parameters can be measured more accurately than protein degradability and MPS in vivo. Furthermore, the main objective of feed protein evaluation systems is to predict protein values of an individual feedstuff or of a diet, production responses to the changes in MP supply and to prevent unnecessary losses of $\mathrm{N}$ to the environment.

The objectives of this paper are to review the current feed protein evaluation systems, especially differences in the concepts of estimating the protein values (1) and to critically discuss the limitations of techniques used to estimate parameter values (2). Validation of different approaches to estimate the microbial component of MP using data from production experiments was conducted. This review will mainly focus on empirical models based on factorial approaches. The mechanistic models estimating microbial protein synthesis have been described in detail by Dikstra et al. (1998).

\section{MICROBIAL PROTEIN SYNTHESIS}

\section{Available energy}

Microbial protein synthesised in the rumen provides a majority of amino acids (AA) flowing to the small intestine of dairy cows (Clark et al., 1992) and therefore understanding the mechanisms and control of MPS is essential for optimizing the performance of dairy cows. Microbial protein synthesis is related to the amount of available of substrates providing ATP and carbon for rumen microbes. When the supply of rumen degradable protein (RDP) does not meet the requirements of microbes, potential MPS from available energy is generally discounted.

In empirical protein evaluation systems a wide range of equations are used to predict MPS from the content of digestible organic matter (DOM) or comparable 
easily available parameter (Table 1). A major problem of this approach is that variable proportions of digestible substrates are fermented in the rumen and that the substrates provide a variable amount of energy for rumen microbes. Variable discounts are made for the substrates providing no energy for microbial growth in most of the current protein evaluation systems (Table 1). However, none of the systems appears to be complete on theoretical basis in calculating available energy supply for rumen microbes.

Table 1. The basis of calculating energy availability for microbial growth in the rumen and discounts for available energy according to some protein evaluation models

\begin{tabular}{lcccccc}
\hline \multirow{2}{*}{ Basis } & AFRC & INRA & NRC & Dutch & AAT/PBV & $\begin{array}{c}\text { AAT/PBF } \\
\text { (FIN) }\end{array}$ \\
\cline { 2 - 7 } & $\begin{array}{c}\text { Fermentable } \\
\text { ME }\end{array}$ & DOM & TDN ${ }^{1}$ & DOM & $\begin{array}{c}\text { Digestible } \\
\text { CHO }\end{array}$ & $\begin{array}{c}\text { Digestible } \\
\text { CHO + RDP }\end{array}$ \\
\hline Discounts & & & & & & \\
$\quad$ fat & Yes & Yes & No & Yes & Yes & Yes \\
ferm. products & Yes & Yes & No & Yes $(0.50)^{3}$ & No & No \\
RUP $^{1}$ & No & Yes & No & Yes & Yes & Yes \\
RDP $^{2}$ & No & No & No & No & Yes & No \\
escape starch & No & No & No & Yes & No & No \\
escape NDF & No & No & No & No & No & No \\
\hline
\end{tabular}

${ }^{1}$ RUP - rumen undegraded protein

${ }^{2} \mathrm{RDP}$ - ruminally degradable protein

${ }^{3}$ corrected for 0.50 of the fermentation end-products

Except for the NRC (2001) system, all other systems discount fat (ether extract) from the available substrates. In the NRC (2001) system fat has actually a very strong contribution to MPS because a factor of 2.25 is used for fatty acids [(ether extract $-10(\mathrm{~g} / \mathrm{kg} \mathrm{DM})]$ to calculate total digestible nutrients (TDN). In spite of being theoretically incorrect, standard error of prediction was not higher for TDN compared with total tract DOM (NRC, 2001). It was discussed that improved efficiency of MPS may compensate for the reduced rumen fermentability with increased fat intake.. Based on the relatively small variation in dietary fat content and possible increases in the efficiency of MPS with increased fat content, discounting fat from DOM may not have a major contribution on the prediction accuracy of MPS.

On a theoretical basis (Chamberlain, 1987) and experimental evidence (Jaakkola and Huhtanen, 1992), it is clear that the end-products of silage fermentation are not a significant source of energy for rumen microbial growth. Discounts for the fermentation products are taken into account completely (Vérité and Peyraud, 1989; AFRC, 1992), partly (Tamminga et al., 1994) or they are totally ignored (Madsen et al., 1995; NRC, 2001). Although theoretically justified, it appears that 
the benefits from restricted compared with extensive in-silo fermentation in terms of milk protein output are mainly restricted to the intake effects (Huhtanen et al., 2003). Diets based on restrictively fermented grass silages containing minimal amounts of fermentation acids are characterized by a rumen fermentation pattern rich in lipogenic volatile fatty acids associated with a relatively high efficiency of MPS compared with diets based on high lactate silages, which are associated with rumen fermentation pattern rich in propionate and a lower efficiency of MPS (Chamberlain and Choung, 1993; van Vuuren et al., 1995). These general considerations of the effects of silage fermentation characteristics suggest that diets based restrictively fermented silages are more limited in the supply of glucose and probably more amino acids are used for glucose synthesis in the liver thereby reducing their availability in the mammary gland. In a validation of protein evaluation systems by means of milk production experiments carried out in Finland (Tuori et al., 1998; Schwab et al., 2005) the systems discounting for the effects of fermentation products (INRA, AFRC) were less accurate in predicting milk protein yield responses than the Danish and Finnish versions of the AAT/ PBV system, which do not take fermentation products into account. Discrepancy between theoretical concepts and validation from production studies address the importance of dynamic mechanistic models, by which substrate interactions in metabolism can better be taken into consideration.

Undegraded feed protein does not provide energy for rumen microbes, which is taken into account in the current protein evaluation systems except for the AFRC (1992) and NRC (2001) systems. The fermentation of protein provides much less energy to rumen microbes than carbohydrates (Tamminga, 1979), but all the empirical protein systems ignore this concept. In this view systems discounting for RDP as an energy source (e.g., Scandinavian AAT/PBV; Madsen et al., 1995) and those providing rumen microbes with similar amounts of energy per unit of protein and carbohydrates fermented (e.g., PDI; Vérité and Peyraud, 1989) are equally correct. In a comparison of feed protein evaluation systems using data from production experiments carried out in Finland (157 diets) including RDP in addition to digestible $\mathrm{CHO}$ (DCHO) as energy sources for MPS decreased significantly the mean square prediction error in the ratio of supply to requirement (Tuori et al., 1998). Consequently, calculation MPS on the basis of RDP+DCHO was adopted in the Finnish AAT/PBV system. There is experimental evidence, mainly from in vitro studies, indicating that increased supply of preformed AA and peptides stimulate microbial growth (see Dikstra et al., 1998; Schwab et al., 2005) thereby compensating for the lower energy supply from fermentable protein compared with carbohydrates.

There are considerable differences in the proportion of ruminal digestion of the total starch digestion (Nocek and Tamminga, 1991). However, only the Dutch DVE/ OEB system (Tamminga et al., 1994) discounts for the ruminally undegraded starch 
from the available substrates. Undegraded starch is estimated by the in situ technique assuming that proportionally 0.10 of immediately degradable starch escapes from ruminal degradation (Nocek and Tamminga, 1991). Theoretically, a similar discount from DOM should be made for the post-ruminally fermented NDF.

Possible contribution of the substrates to the available energy supply for microbial growth in the rumen is illustrated in Table 2 for a diet comprised of grass silage, grain and protein supplement (500, 400 and $100 \mathrm{~g} / \mathrm{kg}$ on DM basis).

Table 2. Calculated discounts in the available energy for a diet of grass silage-barley and rapeseed meal (0.50-0.40-0.10 on DM basis) using with the possible range in practise

\begin{tabular}{|c|c|c|c|c|c|c|}
\hline & \multirow[b]{2}{*}{ low } & \multirow[b]{2}{*}{ high } & \multicolumn{2}{|c|}{ Discount, $\mathrm{g} / \mathrm{kg} \mathrm{DM}$} & \multicolumn{2}{|c|}{ Proportional discount } \\
\hline & & & low & high & low & high \\
\hline $\mathrm{FP}^{1}, \mathrm{~g} / \mathrm{kg}$ silage $\mathrm{DM}$ & 40 & 120 & 20.0 & 60.0 & 0.027 & 0.081 \\
\hline Ammonia, $\mathrm{g} / \mathrm{kg}$ silage $\mathrm{N}$ & 40 & 120 & 3.2 & 9.6 & 0.004 & 0.013 \\
\hline $\mathrm{RUP}^{2}, \mathrm{~g} / \mathrm{kg} \mathrm{CP}$ & 200 & 400 & 33.7 & 67.3 & 0.045 & 0.091 \\
\hline $\begin{array}{l}\text { Starch escape, } \mathrm{g} / \mathrm{kg} \\
\text { starch }\end{array}$ & 100 & 300 & 24.2 & 72.6 & 0.033 & 0.098 \\
\hline NDF escape, $g / \mathrm{kg} \mathrm{DNDF}^{3}$ & 0 & 200 & 0.0 & 51.4 & 0.000 & 0.069 \\
\hline Total & & & 81.1 & 261.0 & 0.109 & 0.351 \\
\hline
\end{tabular}

${ }^{1} \mathrm{FP}$ - fermentation products

${ }^{2}$ RUP - rumen undegraded protein

${ }^{3} \mathrm{DNDF}$ - potentially digestible NDF

The content of DOM was estimated to be $743 \mathrm{~g} / \mathrm{kg}$ DM. Assuming that the silage was restrictively rather than extensively fermented, barley instead of maize was the energy source (proportional starch escape 0.10 vs 0.30 ), ruminal protein degradability ( 0.80 vs 0.60$)$ and proportion of ruminal NDF digestion (1.00 vs 0.80 ) were reduced, the proportional difference in the available substrate supply for rumen microbes was 0.27 . This probably reflects a maximum range in the availability of substrates for microbial growth and corresponds a difference of 17 to $20 \mathrm{~g}$ MP per $\mathrm{kg}$ DM. The NRC (2001) criticized the use of fermentable OM as an index of available energy for rumen microbes, since there is no adequate means by which rumen fermentability of an individual feedstuff or diet can be predicted. According to Vérité and Peyraud (1989) additional parameters (fat, fermentation products, RUP) are easily available for a large set of feeds. Including undegraded starch and post-ruminal NDF digestion in the estimation of available substrates needs further evaluation. The benefits of using these additional parameters should be weighted against increased complexity of the system and the limitations of the current techniques used to determine ruminal starch and NDF digestibility. Despite that empirical protein evaluation systems discounting for the substrates providing no energy for microbial growth are theoretically more correct, there is little evidence for an improved prediction accuracy of milk protein responses (Schwab 
et al., 2005). However, the validation of equations describing the relationship between feed input and MPS using the data from production experiments are often confounded by other differences in the systems.

\section{Evaluation of models estimating microbial protein synthesis}

The effect of computing the microbial protein component on prediction accuracy of milk protein yield was tested using the data from 43 feeding experiments (274 diets). The diets were based on grass silage, cereal grain based energy supplements and protein supplements. The data had a wide range in DM intake (12.9-25.2 $\mathrm{kg} / \mathrm{d}$ ), milk yield (13.0-36.3 kg/d), proportion of concentrate $(0.22-0.58)$ and dietary CP concentration (111-223 g/kg DM). Microbial protein was estimated from ME intake (1), total digestible carbohydrates (DCHO) (2), DCHO + RDP (3), DCHO +0.5RDP (4), and from DCHO + RDP discounted for fermentation acids (lactic acid + VFA) (5), undegraded starch assuming that proportionally 0.15 of starch escapes ruminal fermentation (6) and for both fermentation acids and undegraded starch (7). The coefficient of the efficiency of MPS was adjusted so that the estimated microbial protein supply, and consequently, the contribution of microbial protein to the total MP supply were the same for all equations. The relationship between estimated MP supply and milk protein yield was computed using a mixed model regression analysis with a random study effect or a simple regression analysis. The relationship between calculated MP requirement and estimated MP supply was estimated by a linear regression analysis. The mean squared prediction error (MSPE) was calculated as $\left.\left(\sum \text { (supply - requirement }\right)^{2}\right) / \mathrm{n}$ where $\mathrm{n}=274$. The MSPE was decomposed into error due to the overall bias, error due to deviation of the slope from unity, and error due to variation around the regression line (Bibby and Toutenburg, 1977).

Relationships between MP supply and milk protein yield estimated using the mixed model analysis, i.e. within a study, are shown in Table 3. Differences in prediction accuracy were relatively small. Estimating microbial component of MP from ME intake predicted differences in milk protein yield within a study almost as accurately as the best equations despite theoretical limitations. This could be associated with relatively small variation in RUP and fat concentration of the diet as indicated by the strong correlation between $\mathrm{ME}$ and $\mathrm{DCHO}+\mathrm{RDP}$ intakes $\left(\mathrm{R}^{2}=\right.$ 0.993). Including RDP in the available substrate for MPS improved the prediction accuracy of milk protein yield, in agreement with Tuori et al. (1998). Discounting proportionally 0.50 of RDP from the available substrate did not improve the prediction accuracy compared with $\mathrm{DCHO}+\mathrm{RDP}$, although degradable protein supplies less energy for microbial growth than carbohydrates (Tamminga, 1979). It is possible that RDP provides more preformed amino acids, which are directly incorporated to microbial protein. Alternatively, less ammonia is fixed by 
glutamine synthetase, which fixes ammonia at low concentrations and requires the expenditure of ATP in contrast to glutamate dehydrogenase, which fixes ammonia at high concentrations.

Table 3. The effect of available substrate for microbial protein on the linear relationships between predicted supply of MP and milk protein yield $(\mathrm{Y}=\mathrm{A}+\mathrm{BX})$ estimated by a mixed model regression analysis with random study effect

\begin{tabular}{lrrcccc}
\hline & A & S.E. & B & S.E & RMSE $^{2}$ & Adj R $^{2}$ \\
\hline ME $^{3}$ & 138 & 21.9 & 0.415 & 0.012 & 20.0 & 0.957 \\
DCHO $^{4}$ & 51 & 24.2 & 0.465 & 0.013 & 20.4 & 0.964 \\
DCHO+RDP $^{5}$ & 89 & 22.2 & 0.442 & 0.012 & 19.3 & 0.963 \\
DCHO+0.5*RDP $^{*}$ & 64 & 22.5 & 0.458 & 0.012 & 19.1 & 0.966 \\
DCHO+RDP-FP $^{6}$ & 133 & 23.5 & 0.418 & 0.013 & 21.7 & 0.952 \\
DCHO+RDP-USta $^{7}$ & 99 & 22.8 & 0.437 & 0.012 & 20.0 & 0.959 \\
DCHO+RDP-FP-USta & 138 & 23.8 & 0.415 & 0.013 & 22.0 & 0.950 \\
\hline
\end{tabular}

${ }^{1}$ S.E - standard error

${ }^{2}$ RMSE - residual mean squared error (adjusted for random study effect)

${ }^{3} \mathrm{ME}$ - metabolizable energy

${ }^{4} \mathrm{DCHO}$ - digestible carbohydrates

${ }^{5} \mathrm{RDP}$ - ruminally degradable protein

${ }^{6} \mathrm{FP}$ - fermentation products

${ }^{7}$ USta - undegraded starch

Interestingly, subtracting the fermentation products from the total amount of DCHO+RDP resulted in a lower prediction accuracy of milk protein yield. As discussed before in this review, extensively fermented silages are characterized by a rumen fermentation pattern rich in propionate, which is the most important substrate for gluconeogenesis, whereas feeding restrictively fermented silages is characterized by a rumen fermentation pattern rich in lipogenic VFA. It is possible that increased microbial protein from restrictively fermented silages is not fully realized as enhanced milk protein yield due to increased utilization of absorbed amino acids for gluconeogenesis. The lower utilization of absorbed AA from restrictively fermented silages can, at least partly, be associated with imbalanced profile of absorbed AA. Histidine is the first limiting AA in dairy cows fed diets based on grass silage and cereal grain supplements (Vanhatalo et al., 1999; Schwab et al., 2005). Because histidine content is microbial protein is markedly lower than in milk protein (20-21 vs $26-27 \mathrm{~g} / \mathrm{kg} \mathrm{AA}$ ), utilization of additional MP derived from microbial protein may be compromised by a sub-optimal AA profile. This example demonstrates that incorporating new elements into factorial protein evaluation systems may not improve the prediction accuracy despite being justified theoretically. It is possible that the error from ignoring the effects of fermentation products was compensated for by the changes in the efficiency of the utilization of absorbed AA. Discounting for the effects of fermentation acids could improve 
the prediction accuracy of milk protein yield providing that the effects on glucose supply and amino acid profile could also be taken into account.

Subtracting undegraded starch from the available substrate for MPS resulted in a slightly reduced prediction accuracy of milk protein yield. This could be due to using a constant proportion of the starch escape (0.15). However, knowing the practical difficulties in determination ruminal starch degradability and the cost of additional analysis, it is unlikely that incorporating undegraded starch in the current factorial protein evaluation models would markedly influence the accuracy of predicted MP values.

Relationship between the MP supply and requirement including the total variance and distribution of variance resulting from bias, slope and random variation are shown in Table 4 . The mean bias was small $(16 \mathrm{~g} / \mathrm{d})$ and variance resulting from the slope error (deviation from unity) was relatively small representing proportionally from 0.06 to 0.14 of the total variance. Subtracting RDP, fermentation acids and starch from the available substrate $(\mathrm{DCHO}+\mathrm{RDP})$ increased the total variance between MP supply and requirement. Increased variance resulted both from the slope and random variance; variance due to bias was by definition similar.

Table 4. Parameters of the regression equation: MP requirement $(\mathrm{g} /$ day $)=$ intercept + slope $\times \mathrm{MP}$ supply (g/day) estimated using different equations for microbial protein synthesis, total variance between MP supply and requirement and the distribution of variance between the variance resulting from bias, slope and random variation

\begin{tabular}{lccccccc}
\hline & \multirow{2}{*}{ Intercept } & \multirow{2}{*}{ Slope } & \multirow{2}{*}{ Adj. $\mathrm{R}^{2}$} & \multicolumn{2}{c}{ Total } & \multicolumn{3}{c}{ Proportion of variance } \\
\cline { 6 - 8 } & & & & variance & Bias & Slope & Random \\
\hline ME $^{1}$ & 163 & 0.900 & 0.903 & 5223 & 0.048 & 0.098 & 0.854 \\
DCHO $^{2}$ & 161 & 0.902 & 0.895 & 5592 & 0.044 & 0.088 & 0.868 \\
DCHO+RDP $^{3}$ & 124 & 0.922 & 0.908 & 4777 & 0.052 & 0.062 & 0.886 \\
DCHO+0.5*RDP & 129 & 0.920 & 0.909 & 4784 & 0.052 & 0.067 & 0.881 \\
DCHO+RDP-FP $^{4}$ & 207 & 0.876 & 0.896 & 5885 & 0.042 & 0.141 & 0.817 \\
DCHO+RDP-USta $^{5}$ & 133 & 0.917 & 0.897 & 5327 & 0.046 & 0.064 & 0.890 \\
DCHO+RDP-FP-USta & 211 & 0.874 & 0.889 & 6217 & 0.040 & 0.138 & 0.823 \\
\hline
\end{tabular}

${ }^{1}$ ME - metabolizable energy

${ }^{2} \mathrm{DCHO}$ - digestible carbohydrates

${ }^{3} \mathrm{RDP}$ - ruminally degradable protein

${ }^{4} \mathrm{FP}$ - fermentation products

${ }^{5}$ USta - undegraded starch

\section{Effects of feeding level and nutrient interactions}

Most of the protein evaluation systems assume that the supply of fermentable energy for microbial growth per $\mathrm{kg}$ DM is independent of the feeding level, although it is well recognized that the digestibility diets fed to dairy cows is reduced with increasing feed intake (Tyrrel and Moe, 1975). The rate of decline in 
digestibility per multiple of maintenance increases with digestibility measured at the maintenance level (NRC, 2001). In the NRC (2001) system MPS is estimated from TDN discounted for the decline in digestibility with increased intake. This adjustment is made continuously across all levels of feeding.

Greater declines in digestibility with increased feed intake for the concentrate diets (high TDN) may be related to the lower rumen $\mathrm{pH}$ and associated decreases in the rate of fibre digestion. Diet NDF digestibility is decreased and that of OM unaffected with increased concentrate supplementation of dairy cow diets based on high quality grass silages (Huhtanen, 1998). As a result of these negative associative effects in digestion, the supply of fermentable energy in cows fed high proportions of concentrate at high feeding levels is less than predicted. Empirical equations have been incorporated in some dynamic models to characterize reduced fibre digestion at low rumen $\mathrm{pH}$ (Dikstra et al., 1998), but except for the NRC (2001) system, fermentable energy supply is not corrected for the adverse effects of increased concentrate feeding. Whether these discounts would be useful in empirical models is unclear. Under these circumstances the supply of glucose both from ruminal propionate production and intestinal starch absorption could be increased, which could enhance the efficiency of milk protein production by sparing AA from catabolism in the liver.

\section{Efficiency of microbial protein synthesis}

Most of the empirical protein evaluation systems assume a constant value for the efficiency of microbial N synthesis. Only the AFRC (1992) system assumes that efficiency of MPS increases with the feeding level. However, the amount of fermentable energy is not discounted for the decline in digestibility with increased feeding level, which may lead to an overestimation of MPS with increased feed intake. In contrast to the AFRC (1992) system, the NRC (2001) system adjusts TDN intake for the decline in digestibility, but ignores possible increases in the efficiency of MPS with increased DM intake.

In empirical protein evaluation systems MPS is usually calculated in a discontinuous manner, i.e. the lower value of the potential MPS according to fermentable energy or rumen degradable N (Dikstra et al., 1998). This approach assumes that microbial protein flowing to the small intestine can never exceed the intake of rumen degradable N. However, when RDP intake is low, recycling of urea into the rumen may contribute significant amounts of $\mathrm{N}$ to rumen bacteria.

Prediction accuracy of milk protein yield responses for the AFRC (1992), INRA and NRC (2001) systems were better, when MPS was estimated from fermentable energy rather than using a lower value of the potential MPS based on fermentable energy and RDP supply (Figure 1; Schwab et al., 2005). The data 


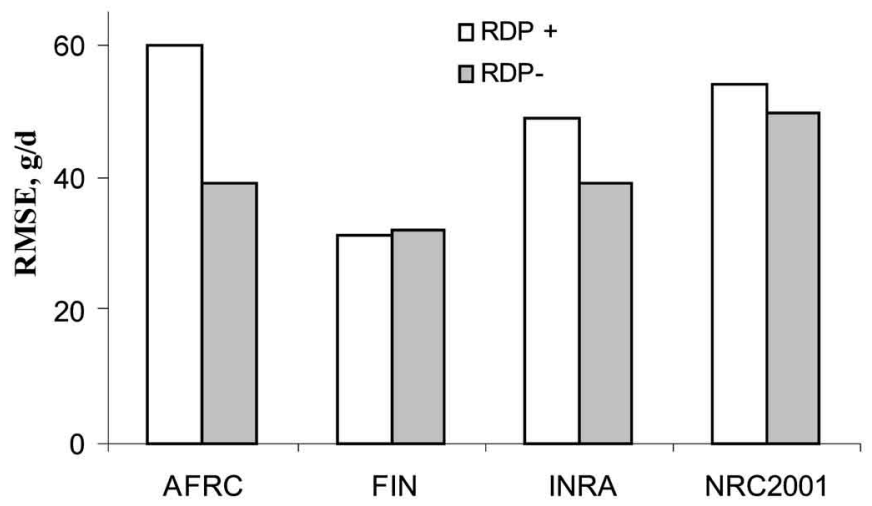

Figure 1. Prediction error of milk protein yield when the MP supply was estimated according to different protein evaluation systems either discounting microbial protein synthesis for deficient supply of RDP (RDP +) or calculating microbial protein on the basis of available energy (RDP -). The results are based on a simple regression analysis $(\mathrm{n}=72$ diets $)$

set (72 diets) included 8 diets with CP concentration below $125 \mathrm{~g} / \mathrm{kg}$ DM, i.e. RDP supply was likely to be limiting at least for some diets. For these diets the $\mathrm{RDP}$ requirements (zero rumen $\mathrm{N}$ balance) were met on average at dietary $\mathrm{CP}$ concentrations of $159,134,123,139$ and $133 \mathrm{~g} / \mathrm{kg}$ DM according to AFRC, DK, FIN, INRA and NRC systems, respectively. When the total MP was estimated by calculating the microbial MP from fermentable energy without discounting for the RDP deficit, milk protein yield responses were generally predicted more accurately. Improvement in the prediction accuracy of milk protein yield was greatest for the AFRC (1992) system, which suggests that overestimation of the true RDP requirement was the highest in this system. Analysis of non-ammonia N flow to the omasum indicated that the zero rumen $\mathrm{N}$ balance was obtained when the dietary CP concentration was $131 \mathrm{~g} / \mathrm{kg} \mathrm{DM}$ and mean daily rumen ammonia $\mathrm{N}$ concentration $4 \mathrm{mmol} / \mathrm{L}$ (Schwab et al., 2005). The contribution of endogenous $\mathrm{N}$ to NAN flows is likely to be smaller with omasal sampling compared with duodenal sampling, and therefore, consequent RDP requirements based on data derived from duodenal sampling are overestimated. It may be concluded that with practical dairy cow diets MPS is very seldom compromised by limited RDP supply, because protein supplements are generally fed.

There are some differences between the systems in the values for the amino $\mathrm{N} /$ total $\mathrm{N}$ ratio in microbial $\mathrm{CP}$ and true absorption for amino $\mathrm{N}$. However, the combined effect these factors are very small except for the Nordic system (Madsen et al., 1995), in which the lower amino $\mathrm{N} /$ total $\mathrm{N}$ ratio in microbial $\mathrm{CP}$ (0.70) leads lower conversion of microbial CP to MP (0.595) compared with most of the other systems $(0.64 ; 0.75 \times 0.85$ or $0.80 \times 0.80)$. 


\section{FEED PROTEIN SUPPLY}

\section{Ruminal protein degradability}

Ruminal degradation of dietary $\mathrm{CP}$ is an important factor influencing the total supply of absorbed amino acids available for host animal metabolism. At present, the in situ technique is widely used to describe the ruminal degradation characteristics of a feedstuff because it is a relatively simple and low-cost method compared with intestinally cannulated animals. The details and limitations of the method have been extensively reviewed (Nocek, 1988; Michalet-Doreau and Ould-Bah, 1992; Stern et al., 1997; Nozière and Michalet-Doreau, 2000). In addition to technical and biological problems associated with the in situ technique discussed in these reviews, low repeatability and lack of reproducibility are serious limitations of the method. Despite many serious attempts to standardize the in situ method, ring tests have shown considerable variation among laboratories. For example, ruminal protein degradability of soyabean meal varied from 40 to $80 \%$ (Madsen and Hvelplund, 1994).

In this review quantitative aspects of the in situ method in estimating effective ruminal protein degradability (EPD) are discussed. The progress in this field has been rather limited, mainly because of the lack of reliable in vivo reference data. Determination of protein degradability in vivo involves the use of animals fitted with an abomasal or a duodenal cannula and the use of digesta flow and microbial markers to measure microbial protein synthesis. Undegraded feed $\mathrm{N}$ flow is calculated as a difference between non-ammonia N (NAN) and microbial $\mathrm{N}$ with or without corrections for an assumed contribution of endogenous $\mathrm{N}$. In addition to variation both between and within the laboratories, these studies are expensive and time-consuming, and can not therefore be considered for routine feed evaluation. Omasal sampling technique is another alternative to determine protein degradability in vivo. Smaller endogenous contribution is an advantage of the method, but it has most of the other disadvantages of duodenal sampling technique. However, a close within study relationship between omasal NAN flow and milk protein yield in six studies (Ahvenjärvi, 2002) suggests that the technique might be a useful tool for producing reference data for alternative techniques.

The effective protein degradability is calculated from the in situ degradation kinetic parameters and passage rate using the model suggested by Ørskov and McDonald (1979): $\mathrm{EDP}=\mathrm{A}+\mathrm{B} \times \mathrm{k}_{\mathrm{d}} /\left(\mathrm{k}_{\mathrm{d}}+\mathrm{k}_{\mathrm{p}}\right)$, where A represents immediately soluble fraction, $B$ represents insoluble but potentially degradable fraction, $\mathrm{k}_{\mathrm{d}}$ is the degradation rate constant and $\mathrm{k}_{\mathrm{p}}$ is estimated fractional outflow rate from the rumen. Implicit in the in situ method is that the rapidly degradable fraction (Afraction) is solubilized at time zero, and is assumed to have a degradation rate of infinite with no escape. Recent studies (Choi et al., 2002a; Volden et al., 2002) 
have clearly demonstrated that variable proportions of dietary $\mathrm{N}$ can escape from the rumen in the liquid phase as non-ammonia non-microbial N. To overcome this problem, Hvelplund and Weisbjerg (2000) proposed a model in which the escape of the A-fraction is incorporated into the model. In the Dutch feed protein scheme (Tamminga et al., 1994) it is assumed that proportionally 0.05 of the soluble protein washed out from the nylon bags escapes from the rumen before being degraded.

In addition to truly soluble crude protein, the A-fraction consists of small particles escaping the bags in zero hour washing procedure. Hvelplund and Weisbjerg (2000) presented a correction equation for the particle loss from nylon bags, but their approach may also present some problems because it assumes the same degradation characteristics for the escaped particles as for the original feed sample. Another problem, though often ignored, is a secondary particle loss during the incubation. It is possible that with increased incubation time the particle size decreases and the particles become eligible for the escape.

One serious problem in our current systems for estimating ruminal protein degradability is the kinetic models that are used to estimate degradability from degradation kinetic parameters and passage rates. The most commonly used Ørskov and McDonald (1979) model assumes that the rumen is a single compartment system and that the probability of particles escaping the system is independent of factors such as particle size, functional specific gravity, age, etc. However, studies involving duodenal digesta sampling have clearly demonstrated selective retention of externally (Pond et al., 1988; Ellis et al., 1994) and internally (Huhtanen and Hristov, 2001) labelled forage particles in the rumen. Because of the smaller particle size of concentrates as compared with forages, it could be assumed that concentrate particles are not selectively retained in the rumen and follow the same passage kinetics as liquid phase markers. Duodenal marker profiles of labelled concentrate feeds have clearly shown an ascending phase in the marker excretion curve (Huhtanen et al., 1993; Mambrini and Peyraud, 1997) indicating that the passage kinetics can not be described by a first-order single pool model. The diurnal pattern of duodenal amino acid (Robinson et al., 2001) and starch (Tothi et al., 2003) flow are consistent with the marker kinetic data. Estimating the $\mathrm{k}_{\mathrm{p}}$ values only from the descending phase of the marker excretion curve will seriously underestimate retention time in the rumen, and consequently, overestimate the supply of UDP. Using the reciprocal of total mean rumen retention time will partly alleviate the problem. A more correct approach would be to use either a two-compartment rumen model that includes selective retention or to estimate simple first order $\mathrm{k}_{\mathrm{p}}$ as suggested by Allen and Mertens (1988): $\mathrm{k}_{\mathrm{p}}=\mathrm{k}_{\mathrm{r}} \times \mathrm{k}_{\mathrm{e}} /\left(\mathrm{k}_{\mathrm{d}}+\mathrm{k}_{\mathrm{r}}+\mathrm{k}_{\mathrm{e}}\right)$, where $\mathrm{k}_{\mathrm{r}}, \mathrm{k}_{\mathrm{e}}^{\mathrm{p}}$, and $\mathrm{k}_{\mathrm{d}}$ are the rate of release from the non-escapable compartment to the escapable compartment, the rate of escape from the escapable compartment, and the rate of digestion, respectively. The simple first-order passage is not only a function of passage kinetic parameters but also of each fraction's digestion rate. 
The estimates of passage rates used to calculate EDP values are highly variable in the new protein evaluation systems. In the AFRC (1992) scheme the passage rate increases with enhanced feeding level, and a value of 0.096 per $\mathrm{h}$ both for forages and concentrates is used at a feeding level of four times the ME required for maintenance (about $20 \mathrm{~kg}$ DM per day). In the NRC (2001) system the $\mathrm{k}_{\mathrm{p}}$ values are regulated by DM intake and proportion of forage in the diet. The NRC (2001) equation results in a value of 0.057 for a passage rate of forage particles in a cow eating $20 \mathrm{~kg} \mathrm{DM} / \mathrm{d}$. Other systems (Vérité and Peyraud, 1989; Tamminga et al., 1994) use constant values of 0.060 and 0.045 for the passage rate of forage particles irrespective of feeding level. The constant values were justified by application of the systems to productive animals fed near or at ad libitum intake. In all of these systems the passage rate estimates are markedly higher than the values estimated for indigestible NDF (INDF) using rumen evacuation technique (Huhtanen et al., 2005). At a DM intake of $20 \mathrm{~kg} / \mathrm{d}(8 \mathrm{~kg}$ NDF) their equation derived from Danish and Finnish data (41 diets) predicts a value of 0.026 per $\mathrm{h}$ for the $\mathrm{k}_{\mathrm{p}}$ of INDF. Two reasons for the large differences in passage rate estimates used in feed protein evaluation systems and those derived for INDF from rumen evacuation data can be suggested: default values used in protein systems are derived from data based on $\mathrm{k}_{\mathrm{p}}$ values estimated only from the descending phase of marker excretion curves (1) and part of the data is based on the use of rare earths as passage kinetic markers (2). In a recent study (Ahvenjärvi et al., 2004) the use of $\mathrm{Yb}$-labelled silage underestimated compartmental retention time compared with Cr-mordanted silage or internally labelled ADF- ${ }^{15} \mathrm{~N}$. One, although unlikely, explanation is that forage particles with a higher protein content have a faster passage rate than fibre particles

\section{Digestibility of undegraded feed protein}

The undegraded feed protein fraction (RUP) consists of potentially digestible and indigestible fractions. Variable methods are used to estimate intestinal digestion of RUP. In the AFRC (1992) system the digestibility of RUP is calculated from acid detergent insoluble N (ADIN) as follows: digestible RUP $\left(\mathrm{g} \mathrm{kg}^{-1} \mathrm{DM}\right)$ $=0.9$ RUP $-6.25 \mathrm{ADIN}$. This equation assumes that $\mathrm{ADIN}$ is both undegradable in the rumen and indigestible in the small intestine. Although a good relationship between ADIN and N digestibility has been demonstrated for forages and other unprocessed feeds, for heat-treated feeds the relationship is poor (for discussion, see NRC, 2001).

In situ mobile bag technique is another method for estimating intestinal digestibility of RUP. Using this method, small amounts of washed ruminally undegraded feed residues are placed in bags, which are usually pre-incubated in pepsin- $\mathrm{HCl}$ to simulate the hydrolysis in the abomasum. Then the bags are 
inserted into the duodenum of cannulated animals and the bags are recovered either form the ileal cannula or faeces. Factors potentially influencing the accuracy of the estimates of intestinal digestibility of undegraded feed protein are reviewed by Vanhatalo (1994) and Stern et al. (1997). Estimates of RUP digestibility based on the mobile-bag technique are currently used in many feed protein evaluation systems (Tamminga et al., 1994, Madsen et al., 1995, NRC 2001). In the French PDI system (Vérité and Peyraud, 1989) the content of truly indigestible protein (IDP) is derived by subtracting faecal metabolic and endogenous $\mathrm{N}$ from apparently non digestible $\mathrm{CP}$ given in feed tables (i.e. CP-DCP). Digestibility of undegraded feed protein is calculated as (RUP-IDP)/ RUP.

Although the in situ mobile bag technique is widely used for estimating RUP digestibility, only few comparisons with in vivo intestinal $\mathrm{CP}$ digestibility have been made (Vanhatalo 1994). Excluding few outliers the correlation between the results from mobile bag method and intestinal in vivo digestibility was satisfactory. Infusion and ${ }^{15} \mathrm{~N}$ dilution techniques were used in these studies to estimate in vivo intestinal CP digestibility. Another alternatively to produce reference data is to estimate truly indigestible fraction of CP by using the Lucas principle. According to the Lucas principle, the true digestibility of a nutritional entity is determined as the slope of the regression between the amounts of nutrient digested (e.g., crude protein) against the intake of a given nutrient (Van Soest, 1994). True CP digestibility for some feedstuffs estimated by the Lucas principle from the MTT data sets from digestibility studies conducted in dairy cows (protein supplements) and sheep (grass silage) are presented in Table 5.

Table 5. A comparison of true digestibility of incremental crude protein estimated according to the Lucas principle from MTT data and potential CP digestibility derived from the Danish and French feed tables

\begin{tabular}{|c|c|c|c|c|c|c|c|}
\hline & \multirow{2}{*}{ Studies } & \multirow{2}{*}{ Diets } & \multirow{2}{*}{ Digestibility } & \multirow{2}{*}{ S.E. } & \multicolumn{3}{|c|}{ Table values } \\
\hline & & & & & $\mathrm{DK}$ & INRA & NRC \\
\hline $\mathrm{FM}^{1}$ & 2 & 6 & 0.941 & 0.028 & 0.93 & 0.92 & 0.94 \\
\hline $\mathrm{RSC}^{2}$ & 6 & 24 & 0.823 & 0.020 & 0.91 & 0.87 & - \\
\hline $\mathrm{RSM}^{3}$ & 11 & 38 & 0.917 & 0.013 & 0.91 & 0.94 & 0.93 \\
\hline $\mathrm{SBM}^{4}$ & 2 & 5 & 0.979 & 0.022 & 0.97 & 0.96 & 0.98 \\
\hline Grass silage & 7 & 27 & 0.967 & 0.008 & 0.92 & 0.91 & 0.92 \\
\hline WDS $^{5}$ & 5 & 12 & 0.810 & 0.033 & - & - & - \\
\hline
\end{tabular}

${ }^{1} \mathrm{FM}$ - fish meal

${ }^{2} \mathrm{RSC}$ - rapeseed cake (expeller), heat-treated

${ }^{3} \mathrm{RSM}$ - rapeseed meal (solvent extracted)

${ }^{4} \mathrm{SBM}$ - soyabean meal

${ }^{5}$ WDS - wet distiller's solubles 
Estimated true digestibility showed small variation and the values for rapeseed meal, soyabean meal and fishmeal were in very good agreement with the values derived from the French (Jarrige, 1989), Danish (Møller et al., 2000) and NRC (2001) feed tables, whereas true CP digestibility of the primary growth silages estimated by the Lucas principle was markedly higher than the values derived from the feed tables. This discrepancy is likely to be associated with microbial contamination of the mobile bag residues of forage samples (Varvikko and Vanhatalo, 1990) leading to underestimation of intestinal digestion.

The true CP digestibility of heat-moisture treated rapeseed expeller was significantly lower than for the corresponding untreated solvent extracted rapeseed meal $(0.823$ vs 0.917$)$, which is contrast with the estimates based on the mobilebag technique (Vanhatalo et al., 1995; Rinne et al., 1999). True digestibility of wet distiller's solubles (WDS) was also surprisingly low considering that it does not contain any fibre-bound nitrogen. Using the in situ mobile-bag procedure had resulted in a complete digestibility of WDS protein, since ruminal CP degradability was complete for this feed (Choi et al., 2002b). The low digestibility of WDS may be related to the use of a formaldehyde containing reagent both to improve preservation and to reduce ruminal degradability. These observations suggest that the nitrogen disappearing from the mobile bags may not necessarily be absorbed when the feedstuffs are treated to reduce ruminal CP degradability. High proportional disappearance of ADF-bound nitrogen (ADIN) from grass samples (up to 0.40-0.50) from the mobile-bags in the intestines (Vanhatalo et al., 1996) suggests that degraded CP disappearing from the bags may not necessarily be absorbed. Despite disappearance of ADIN, the mobile bag technique tends to underestimate the indigestible fraction of forage $\mathrm{CP}$ compared with the in vivo estimates based on the Lucas principle.

In addition to the limitations of the mobile-bag method to estimate intestinal digestibility of protein supplements treated for reduced ruminal degradability and underestimation of intestinal digestibility of forages, the variation in RUP digestibility can also result from determination of ruminal degradability. The effects of the ruminal CP degradability and the concentration of indigestible CP on the digestibility of RUP and the supply of digestible RUP are shown in Figure 2. Digestibility of RUP was calculated as (RUP - IDP)/ RUP as described by Hvelplund et al. (1992). The values for RUP digestibility calculated using this equation are very sensitive to estimated ruminal degradability, especially when ruminal degradability is approaching the potential true digestibility of CP (1IDP). The total supply of digestible RUP is much more sensitive for the changes in ruminal degradability and for the corresponding changes in the estimate of IDP. For example, underestimating ruminal $\mathrm{CP}$ degradability by 0.10 units $(0.60$ vs 0.70 ) for a protein supplement containing $400 \mathrm{~g} \mathrm{CP} / \mathrm{kg}$ DM overestimates the supply digestible RUP by $40 \mathrm{~g} / \mathrm{kg} \mathrm{DM}$, irrespective of the proportion of IDP in CP 

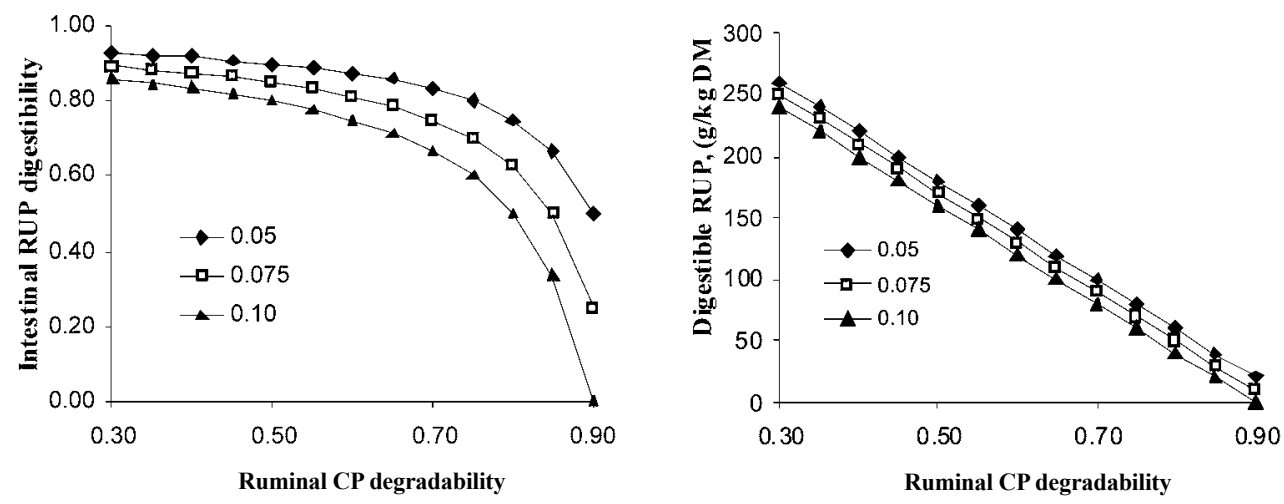

Figure 2. Effects of ruminal CP degradability and proportion of completely indigestible CP on intestinal digestibility of RUP and concentration of digestible RUP of a feed containing $400 \mathrm{~g} \mathrm{CP} / \mathrm{kg} \mathrm{DM}$

(0.050, 0.075 and 0.100 , respectively) when calculated according to Hvelplund et al. (1992). In this case using a constant RUP digestibility of 0.80 had resulted in a smaller bias in digestible RUP content of the feed ( $32 \mathrm{~g} / \mathrm{kg} \mathrm{DM})$. A two-fold error in the estimation of indigestible CP $(0.05$ vs 0.10$)$ resulted only $20 \mathrm{~g} / \mathrm{kg}$ DM bias in digestible RUP supply, i.e. similar to a difference of 0.05 in EDP value.

Validation the effects of protein degradability and digestibility of RUP on MP supply

Because of difficulties in obtaining reliable in vivo reference values for ruminal CP degradability, especially for individual feedstuffs, the procedures estimating the supply of MP from RUP may be validated using the data from production experiments.

The use of a constant ruminal $\mathrm{CP}$ degradability for all feeds rather than values determined by the in situ techniques resulted in a smaller coefficient of variation in the efficiency of MP utilization and in the supply to requirement ratio when variation between experiments were accounted for (Tuori et al., 1998). In a comparison of six different protein evaluation systems the German system (GfE, 1986) predicted variation in milk protein yield better than most of the other systems. Within the GfE system, MP supply was calculated using an equation, which estimates microbial protein from ME and RUP from urea-free crude protein, i.e. the equation assumes a constant $\mathrm{CP}$ degradability. It is unclear why ignoring differences in ruminal degradability and RUP digestibility of feeds did not decrease the prediction accuracy. Despite the in situ procedure has intrinsic problems, research indicates that it does rank feeds fairly well with respect to rumen degradability and intestinal digestibility. The explanation is probably a 
combined effect of errors in estimating RUP, RUP digestibility and predicting MPS. These errors may counterbalance each other, e.g., it is possible that increased RUP supply decreases the efficiency of MPS. Also, and probably more important, the current procedures may overestimate the differences in ruminal degradability; e.g., if the measured values for feeds $\mathrm{A}$ and $\mathrm{B}$ are 60 and 80 and the true values are 65 and 75, then using a constant value 70 can result in a better prediction of milk protein yield than using values of 60 and 80 , even though the feeds were ranked correctly (Schwab et al., 2005).

Most of the problems related to the in situ method tend to increase the range in EPD values. The effects of possible escape of A-fraction and ignoring the first rumen compartment in the kinetic model on the ruminal CP degradability, digestibility and concentration of RUP and digestible RUP in hay and silage (160 $\mathrm{g} \mathrm{CP} / \mathrm{kg} \mathrm{DM}$ ) are demonstrated in Table 6 . The values of $0.55,0.04$ and 0.08 were assumed for the A-fraction, B-fraction and rate of degradation for silage, and $0.25,0.70$ and 0.08 for hay, respectively. A value of 0.04 was used for the $\mathrm{k}_{\mathrm{p}}$ in the Ørskov and McDonald (1979) model. For the two compartment rumen model it was assumed that proportionally 0.30 of the total compartmental retention time occurred in the first compartment and that the passage rate from the second compartment was the same (0.04) for the both models. When the procedures of the current protein schemes, i.e. ignoring the escape of A-fraction in the liquid phase and the retention of feed particles in the lag-rumination compartment, were used, ruminal protein degradability of silage was 0.10 units higher compared with hay. Including the retention of feed particles in the lag-rumination compartment reduced the difference to 0.051 . Acknowledging the escape of A-fraction decreased the difference between hay and silage in the EDP from 0.051 to 0.036 or 0.021 assuming that proportionally $0,0.05$ or 0.10 of the A-fraction escaped ruminal degradation, respectively. The difference between hay and silage in the estimated supply of digestible RUP decreased from 16.0 to $5.7 \mathrm{~g} / \mathrm{kg}$ DM when estimated using the model proposed by Ørskov and McDonald (1979) or incorporation the selective retention of feed particles in the kinetic model and assuming a proportional escape of 0.05 for the A-fraction. The latter value compares much better with the duodenal non-ammonia $\mathrm{N}$ flow estimates (Jaakkola and Huhtanen, 1993) or milk protein yield responses in studies comparing hay and silage harvested from the same sward (Huhtanen, 1994).

Validation of the protein evaluation systems using data from production studies support the view given that current methods and models used to estimate EDP and the supply of undegraded feed protein tend to overestimate the range in the supply of MP. Tuori et al. (1998) observed that using lower $\mathrm{k}_{\mathrm{p}}$ values to estimate RUP supply resulted in a smaller coefficient of variation in the efficiency of MP utilization and supply to requirement ratio when the variation between experiments was accounted for. The use of lower $\mathrm{k}_{\mathrm{p}}$ values decreased the proportional contribution of RUP to the 


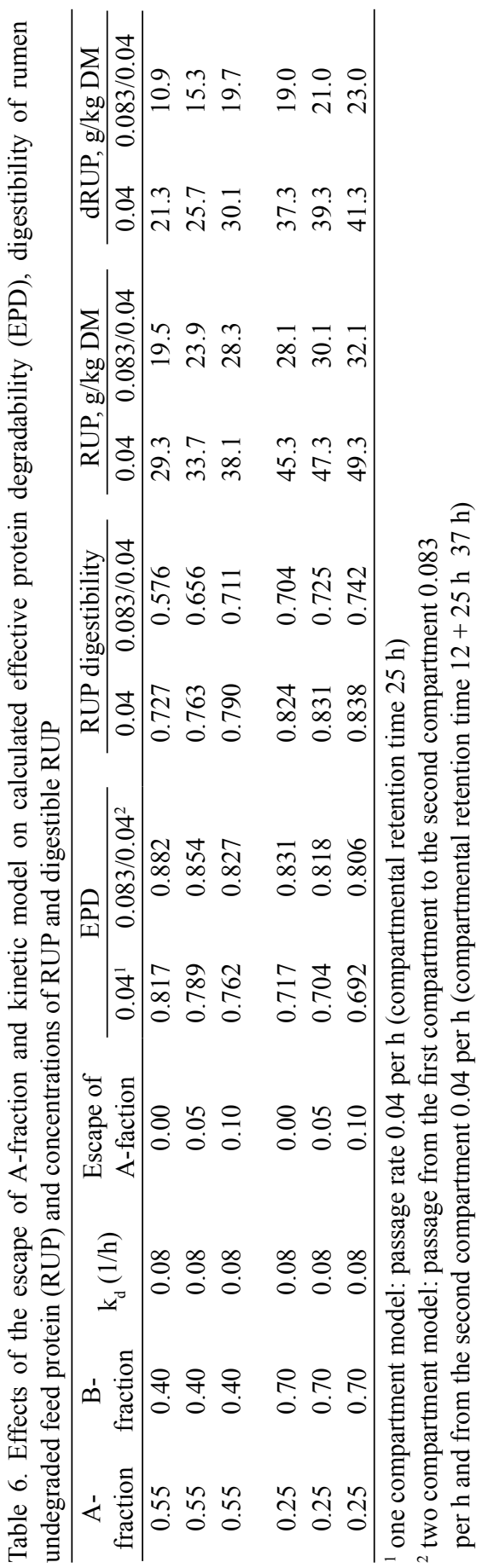


total MP supply and also the range in RUP supply. Schwab et al. (2005) found that a bivariate regression model with microbial MP and feed MP as independent variables predicted the differences in milk protein yield better than the total MP. Interestingly, the slope was markedly higher for the microbial MP compared with feed MP (0.90 vs 0.31 ) suggesting that the value of feed MP was overestimated in relation to microbial MP. Also, the differences between MP supplies and requirements were strongly related to dietary concentration of digestible RUP for the AFRC (1992) and NRC (2001) systems. Van Straalen et al. (1995) compared several protein evaluation systems and found that prediction error of milk protein output was much strongly related to the supply of MP for undegraded feed protein than to MP derived from microbial protein.

Although it is obvious that intestinal digestibility is not constant, the evidence is rather limited in demonstrating decreased prediction error of milk protein yield by using variable values for RUP digestibility. The importance of considering differences in model default values for RUP digestibility was examined by Schwab et al. (2005) in the AFRC and NRC systems by using total RUP or digestible RUP as independent variables together with microbial MP for predicting milk protein yield. There were no differences in prediction accuracy for either the NRC system $(\mathrm{RMSE}=34.7$ vs 35.4$)$ or the AFRC system $(\mathrm{RMSE}=58.8$ vs 58.5$)$ when digestible RUP vs total RUP was used. Smoler et al. (1998) obtained a better prediction of milk protein content using RUP rather than digestible RUP in predicting milk protein content, although digestible RUP might be expected to be more closely related to the supply of amino acids to the mammary gland. These findings suggest that very little can be achieved in the feed protein evaluation models by introducing variable digestibility coefficients based on our current analytical methods. However, the fact that using digestible rather total RUP has not decreased prediction error of milk protein yield may not entirely be related to the limitations of the methods used to estimate intestinal digestibility of RUP, but also to the problems associated with determination of ruminal degradability. It should also be noted that in the cited studies digestible RUP was estimated by using the feed table values rather than measured values. Vanhatalo (1994) discussed that the discrepancy between MP values and production responses could not be elucidated by using measured rather than constant values for intestinal digestibility of RUP.

\section{CONCLUSIONS AND FUTURE PERSPECTIVES}

Despite many theoretical flaws in the current empirical protein systems and limitations of the analytical techniques needed to estimate required parameter values, the current systems estimate milk protein yield responses much better than the models based on CP or digestible CP (DCP). Residual mean square 
prediction errors between intake of DM, ME, DCP and MP estimated according to the Finnish system (Tuori et al., 1998) vs milk protein yield indicate that the new protein system clearly improved the prediction accuracy compared with $\mathrm{CP}$ and especially to DCP, which appeared to be less accurate than CP. The data included 43 studies and 284 treatment means. The differences between CP (or DCP) and MP systems were evident either when analysed with a simple regression analysis or using a mixed model analysis (Figure 3), which accounts for the variation between studies. Intakes of ME and even DM were much more closely associated to milk protein yield than intakes of CP or DCP indicating the importance of microbial protein component in the total MP supply. These findings are in agreement with Beever and Cottrill (1994), who suggested that importance of RUP is overemphasised, and with the validation of protein evaluation systems using data from production experiments (Tuori et al., 1998; Schwab et al., 2005). Compared with bivariate models including ME and CP intake as independent variables MP decreased prediction errors from 42.4 to 39.7 (fixed model) and from 21.7 to 19.4 (mixed model) suggesting that some improvements in prediction accuracy can be obtained by taking into account the variation in EPD between the feeds.

Although the empirical protein models are conceptually similar in their aims to describe $\mathrm{N}$ requirements of rumen microbes and $\mathrm{AA}$ requirements of the host animals, they differ in complexity in estimating available energy for microbial protein synthesis in the rumen, the supply of absorbed AA from feed protein and MP requirements for maintenance and production. Although theoretically valid and justifiable, there is no clear evidence that including new elements of calculating available energy for MPS had improved the prediction accuracy.

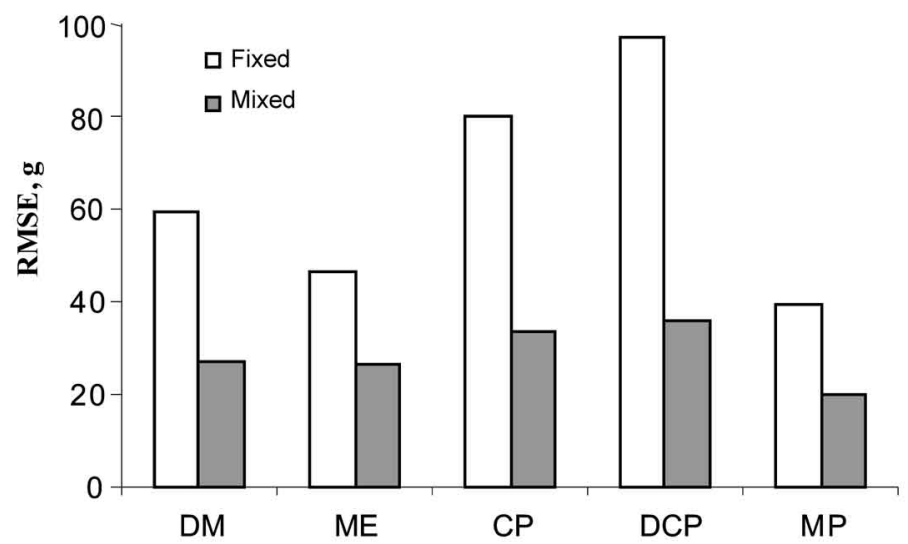

Figure 3. Prediction error in milk protein yield when estimated from intakes of dry matter (DM), metabolisable energy (ME), crude protein (CP), digestible $\mathrm{CP}(\mathrm{DCP})$ or metabolisable protein 
For example, it is possible that discounting fermentation acids and ruminally undegraded starch from the available substrate for MPS improves the prediction accuracy of MP supply from microbial protein, but not necessarily the prediction accuracy of milk protein yield responses because the current systems do not take into account the interactions between glucose and AA supply in the efficiency of AA utilization for milk protein synthesis. Another example is the digestibility of RUP. Because the estimates of RUP digestibility strongly depend on the estimates of ruminal degradability, errors in estimating EPD may explain why the inclusion of variable digestibility of RUP does not necessarily improve the prediction accuracy of milk protein output.

The validation efforts using data from production studies suggest that both the contribution of and the range in the RUP supply are overestimated. This can be, at least partly, attributed to inherent problems of the in situ technique and the kinetic model used to estimate EPD values, and to estimated passage rates often outside the physiological range. The progress in this field has been limited by the lack of reliable in vivo reference data. Although the in situ technique has many limitations, it is very difficult to be replaced in the near future by any alternative techniques. The use of near infrared reflectance spectrometry (NIRS) is an interesting approach, also applicable for practical samples. Although NIRS can satisfactorily predict the in situ degradability characteristics of grasses (Waters and Givens, 1992), these efforts are evidently premature before the in situ has not been rigorously evaluated against in vivo flow measurements or production data.

Because the requirement of the total $\mathrm{AA}$ is often met before the requirement of at least the most limiting essential AA, it can be assumed that the efficiency of MP utilization for milk protein synthesis depends how well the essential AA profile matches the profile required by the animal and the supply of the most limiting essential AA. Because the profile of absorbed AA generally appears to be less than optimum, there appears to be little doubt that the AA requirements need to be defined in terms of individual AA and not as MP. The NRC committee (NRC, 2001) concluded that the knowledge is too limited to put forth a model that quantifies AA requirements for dairy cattle. However, as an alternate and first step NRC (2001) defined the ideal content of EAA in MP. Validation of the NRC (2001) amino acid model showed, as expected, that predicting yields of milk and milk protein from intestinal supplies of the most limiting AA (lysine and methionine) is more precise than predicting yields from MP supply (Schwab et al., 2005). Using the NRC (2001) amino acid model for grass silage based diets $(n=72)$ Huhtanen (2005) observed that His was the only essential AA of which content in MP was positively associated with milk protein yield, in agreement with the findings from infusions studies (Vanhatalo et al., 1999; Kim et al., 2001a). When feather meal was used to further increase the imbalance in AA supply from grass silage-based diets, a substantial milk protein yield response 
to abomasal His infusion was demonstrated (Kim et al. 1999, 2001b) indicating that at least in some circumstances the systems based in metabolizable AA would increase the prediction accuracy of milk protein output.

The prediction accuracy of the current systems may not be considerably improved by revision. Including new empirical and even mechanistic elements may not improve the accuracy of the system due to complicated interactions between dietary components in digestion and absorbed nutrients in metabolism, although they may improve prediction accuracy of some elements of the system, e.g., microbial protein synthesis. Any changes decreasing the relative contribution of RUP to the total MP supply are likely to improve the prediction accuracy, as many of the protein systems tend to overestimate the contribution and range in RUP supply. Predicting the optimal concentration of the most limiting AA in MP could be the first step in balancing the diets for AA supply, but before adoption of the AA models more research to determine optimal AA profile and requirements of individual AA is needed.

In the future the available research resources should be used to develop mechanistic models, which can better take into account interactions in the digestive tract and tissue metabolism. Mechanistic models predicting microbial protein supply in ruminants were described in a review by Dikstra et al. (1998). A Nordic mechanistic dairy cow model was recently described by Danfaer et al. (2005). Although the structures of these models are often theoretically more accurate, their performance may not be better than that of empirical models due to the limitations in our experimental and analytical techniques in estimating the most important parameter values of the models. For example, the drawbacks of the in situ techniques in estimation the rate of cell wall digestion, which is one of the most important parameters of the Danfaer et al. (2005) model influencing the amount of AA absorbed from the small intestine, may be even greater than for protein degradation (Huhtanen et al., 2005). One advantage of the modelling exercises is that they can demonstrate the most important parameters, and research efforts could be focussed to develop and improve the techniques for estimating these parameters.

\section{REFERENCES}

AFRC, 1992. Agricultural and Food Research Council. Energy and Protein Requirements of Ruminants. CAB International. Wallingford (UK), pp. 159

Ahvenjärvi S., 2002. Determination of ruminal feed digestibility and microbial synthesis based on digesta sampling from the omasal canal. PhD Dissertation. University of Helsinki, pp. 30

Ahvenjärvi S., Vanhatalo A., Hristov A.N., Huhtanen P., 2004. Passage kinetics of internal and external markers in lactating dairy cows. J. Anim. Feed Sci. 13, Suppl. 1, 19-22

Allen M.S., Mertens D.R., 1988. Evaluation constraints of fibre digestion by rumen microbes. J. Nutr. 118, 261-270 
Beever D.E., Cottrill B.R., 1994. Protein systems for feeding ruminant livestock: A European assessment. J. Dairy Sci. 77, 2031-2043

Bibby J., Toutenburg H., 1977. Prediction and Improved Estimation in Linear Models. Cp. 1.5.4. Wiley, London, pp. 188

Chamberlain D.G., 1987. The silage fermentation in relation to the utilization of nutrients in the rumen. Process Biochem. 22, 60-63

Chamberlain D.G., Choung J.-J., 1993. The nutritional value of grass silage. In: P. O'Kiely et al. (Editors). Silage Research 1993. Proceedings of the $10^{\text {th }}$ International Conference on Silage Research. Dublin (Ireland), pp. 131-136

Choi C.W., Ahvenjärvi S., Vanhatalo A., Toivonen V., Huhtanen P., 2002a. Quantification of the flow of soluble non-ammonia nitrogen entering the omasal canal of dairy cows fed grass silage based diets. Anim. Feed Sci. Tech. 96, 203-220

Choi C.W., Vanhatalo A., Huhtanen P., 2002b. Concentration and estimated flow of soluble nonammonia nitrogen entering the omasum of dairy cows as influenced by different protein supplements. Agr. Food Sci. Finland 11, 79-91

Clark J.H., Klushmeyer T.H., Cameron M.R., 1992. Microbial protein synthesis and flow of nitrogen fractions to the duodenum of dairy cows. J. Dairy Sci. 75, 2304-2323

Danfær A., Huhtanen P., Udén P., Sveinbjörnsson J., Volden H., 2005. Karoline - a Nordic cow model for feed evaluation - model description. In: J. Dijkstra (Editor). 6th International Workshop Modeling Nutrient Utilisation in Farm Animals. Wageningen Institute of Animal Sciences (in press)

Dikstra J., France J., Davis D.R., 1998. Different mathematical approaches to estimating microbial protein supply to ruminants. J. Dairy Sci. 81, 3370-3384

Ellis W.C., Matis J.H., Hill T.M., Murphy M.R., 1994. Methodology for estimation digestion and passage kinetics of forages. In: G.C. Fahey Jr., M. Collins, D.R. Mertens, L.E. Moser (Editors). Forage Quality, Evaluation and Utilization. American Society of Agronomy, pp. 682-756

GfE, 1986. Ausschuss für Bedarfsnormen der Gesellschaft für Ernährungsphysiologie. Energie und Nährstoffbedarf landwitschaftlicher Nutztiere, Nr. 3. Milchkühe und Aufzuchtrinder. DLGVerlag, Fankfurt am Main (Germany), pp. 92

Huhtanen P., 1994. Forage influences on milk composition. In: A.H. Fredeen (Editor). Proceedings of Nova Scotia Forage Conference. Forage: Seeding to Feeding. Darmouth, Truro, The Nova Scotia Forage Council, pp. 144-162

Huhtanen P., 1998. Supply of nutrients and productive responses in dairy cows given diets based on restrictively fermented silage. Agr. Food Sci. Finland 7, 219-250

Huhtanen P., 2005. A review of the 2001 dairy cattle NRC protein and amino acid model - A European perspective. J. Dairy Sci. 88, Suppl. (in press)

Huhtanen P., Ahvenjärvi S., Weisbjerg M.R., Nørgaard P., 2005. Digestion and passage of fibre in ruminants. Proceedings of the $10^{\text {th }}$ International Symposium in Ruminant Physiology (in press)

Huhtanen P., Hristov A.N., 2001. Estimating passage kinetics using fibre-bound ${ }^{15} \mathrm{~N}$ as an internal marker. Anim. Feed Sci. Tech. 94, 29-41

Huhtanen P., Jaakkola S., Kukkonen U., Nousiainen J., 1993. Influence of passage model in estimating ruminal protein degradability. J. Anim. Sci. 71, Suppl. 1, 263

Huhtanen P., Nousiainen J.I., Khalili H., Jaakkola S., Heikkilä T., 2003. Relationships between silage fermentation characteristics and milk production parameters: analyses of literature data. Livest. Prod. Sci. 81, 57-73

Hvelplund T., Weisbjerg M.R., 2000. In situ techniques for the estimation of protein degradability and postrumen availability. In: D.I. Givens, E. Owen, R.F.E. Axford, H.M. Omed (Editors). Forage Evaluation in Ruminant Nutrition. CAB International, pp. 233-258 
Hvelplund T., Weisbjerg M.R., Andersen L., 1992. Estimation of the true digestibility of rumen undegraded protein in the small intestine of ruminants by the mobile nylon bag technique. Acta Agr. Scand., Sect. A, Anim. Sci. 42, 34-39

Jaakkola S., Huhtanen P., 1992. Rumen fermentation and microbial protein synthesis in cattle given intraruminal infusions of lactic acid with a grass silage based diet. J. Agr. Sci. 119, 411-418

Jaakkola S., Huhtanen P., 1993. The effects of the forage preservation method and the proportion of concentrate on nitrogen digestion and rumen fermentation in cattle. Grass Forage Sci. 48, $146-154$

Jarrige R., 1989. Ruminant Nutrition: Recommended Allowances and Feed Tables. INRA. Libbey Eurotext. Paris (France), pp. 389

Kim C.H., Choung J.J., Chamberlain D.G., 2001a. The effects of intravenous infusion of amino aicds in dairy cows given diets of grass silage and cereal-based concentrates. J. Anim. Physiol. Anim. Nutr. 85, 293-300

Kim C.H., Kim T.G., Choung J.J., Chamberlain D.G., 1999. Determination of the first limiting amino acid for milk production in dairy cows consuming a diet of grass silage and a cereal-based supplement ontaining feather meal. J. Sci. Food Agr. 79, 1703-1708

Kim C.H., Kim T.G., Choung J.J., Chamberlain D.G., 2001b. Estimates of the efficiency of transfer of L-histidine from blood to milk when it is the first-limiting amino acid for secretion of milk protein in the dairy cow. J. Sci. Food Agr. 81, 1150-1155

Madsen J., 1985. The basis for the proposed Nordic Protein Evaluation System for ruminants. The AAT-PBV system. Acta Agr. Scand., Suppl. 25, 9-29

Madsen J., Hvelplund T., 1994. Prediction of in situ protein degradability in the rumen. Results of a European ringtest. Livest. Prod. Sci. 39, 201-212

Madsen J., Hvelplund T., Weisbjerg M.R., Bertilsson J., Olsson I., Spörndly R., Harstad O.M., Volden H., Tuori M., Varvikko T., Huhtanen P., Olafsson B.L., 1995 The AAT/PBV protein evaluation system for ruminants. A revision. Norw. J. Agr. Sci., Suppl. 19, pp. 37

Mambrini M., Peyraud J.L., 1997. Retention time of feed particles and liquids in the stomach of ruminants and intestines of dairy cows. Direct measurements and calculations based on faecal collection. Reprod. Nutr. Develop. 37, 427-442

Michalet-Doreau B., Ould-Bah M.Y., 1992. In vitro and in sacco methods for the estimation of dietary nitrogen degradability in the rumen: a review. Anim. Feed Sci. Tech. 40, 57-86

Møller J., Thøgersen R., Kjedsen A.M., Weisbjerg M.R., Søegaard K., Hvelplund T., Børsting C.F., 2000. Fodermiddeltabelle. Sammansætning og foderværdi af fodermidler til kvæg. Rapport nr. 91. Landbrugets Rådgivningscenter, pp. 52

Nocek J.E., 1988. In situ and other methods to estimate ruminal protein and energy digestibility: A review. J. Dairy Sci. 71, 2051-2069

Nocek J.E., Tamminga S., 1991. Site of digestion of starch in the gastrointestinal tract of dairy cows and its effect on milk yield and composition. J. Dairy Sci. 74, 3598-3629

Nozière P., Michalet-Doreau B., 2000. In sacco methods. In: J.P.F. D'Mello (Editor). Farm Animal Metabolism. CAB International 2000, pp. 233

NRC, 2001. National Research Council. Nutrient Requirements of Dairy Cattle. $7^{\text {th }}$ revised Edition. National Academy Press, Washington, DC

Ørskov E.R., McDonald I., 1979. The estimation of protein degradability in the rumen from incubation measurements weighted according to rate of passage. J. Agr. Sci. 92, 499-503

Pond K.R., Ellis W.C., Matis J.H., Ferreiro H.M., Sutton J.D., 1988. Compartmental models for estimating attributes of digesta flow in cattle. Brit. J. Nutr. 60, 571-595

Rinne M., Jaakkola S., Varvikko T., Huhtanen P., 1999. Effects of the type and amount of rapeseed feed on milk milk production. Acta Agr. Scand., Sect. A, Anim. Sci. 49, 137-148 
Robinson P.H., Gill M., Kennelly J.J., 2002. Influence of time of feeding a protein meal on diurnal patterns of amino acids in duodenal digesta protein of lactating dairy cows. Anim. Feed Sci. Tech. 97, 115-121

Schwab C.G., Huhtanen P., Hunt C.W., Hvelplund, T., 2005. Nitrogen requirements of cattle. In: E. Pfeffer, A.N. Hristov (Editors). Interactions between Cattle and the Environment. CABI Publishing (in press)

Smoler E., Rook A.J., Sutton J.D., Beever D.E., 1998. Prediction of milk protein concentration from elements of he metabolisable protein system. J. Dairy Sci. 81, 1619-1623

Stern M.D., Bach A., Calsamiglia S., 1997. Alternative techniques for measuring nutrient digestion in ruminants. J. Anim. Sci., 75, 2256-2276

Tamminga S., 1979. Protein degradation in the forestomach of ruminants. J. Anim. Sci. 49, 1615-1630

Tamminga S., Van Straalen W.M., Subnel A.P.J., Meijer R.G.M., Steg A., Wever C.J.G., Blok M.C., 1994. The Dutch protein evaluation system: the DVE/OEB-system. Livest. Prod. Sci. 40, 139-155

Tothi R., Lund P., Weisbjerg M.R., Hvelplund T., 2003. Effect of expander processing on fractional rate of maize and barley starch degradation in the rumen of dairy cows estimated using rumen evacuation and in situ techniques. Anim. Feed Sci. Tech. 104, 71-94

Tuori M., Kaustell K.V., Huhtanen P., 1998. Comparison of the protein evaluation systems of feeds for dairy cows. Livest. Prod. Sci. 55, 3-46

Tyrrel H.F., Moe P.W., 1975. Effect of intake of digestive efficiency. J. Dairy Sci., 58, 1151-1163

Vanhatalo A., 1994. Assesment of intestinal feed nitrogen digestibility in ruminant by the mobilebag method. PhD. Dissertation. University of Helsinki, pp. 44

Vanhatalo A., Aronen I., Varvikko T., 1995. Intestinal nitrogen digestibility of heat-moisture treated rapeseed meals as assessed by the mobile bag method in cows. Anim. Feed Sci. Tech. 55, 139-152

Vanhatalo A., Dakowski P., Huhtanen P., 1996. Effects of stage of growth and duration of rumen incubation time on digestibility of rumen-undegradable nitrogen of grass by mobile-bag method in cows. Acta Agr. Scand., Sect. A, Anim. Sci. 46, 1-10

Vanhatalo A., Huhtanen P., Toivonen V., Varvikko T., 1999. Response of dairy cows fed grass silage diets to abomasal infusions of histidine alone or in combinations with methionine and lysine. J. Dairy Sci. 82, 2674-2685

Van Soest P.J., 1994. Nutritional Ecology of Ruminants. $2^{\text {nd }}$ Edition. Cornell University Press, Ithaca (USA), pp. 476

Van Straalen W.M., Salaün C., Veen W.A.G., Rijpkema Y.S., Hof G., Boxem T.J., 1995. Validation of protein evaluation systems by means of milk production experiments with dairy cows. Neth. J. Agr. Res. 42, 89-104

Van Vuuren A.M., Huhtanen P., Dulphy J.-P., 1995. Improving the feeding and health value of ensiled forages. In: M. Journet et al. (Editors.). Recent Developments in the Nutrition of Herbivores. INRA, Paris, pp. 297-307

Varvikko T., Vanhatalo A., 1990. The effect of differing types of cloth and of contamination by nonfeed nitrogen on intestinal digestion estimates using porous synthetic-fibre bags in a cow. Brit. J. Nutr. 63, 221-229

Vérité R., Peyraud J.-L., 1989. Protein: the PDI system. In: R. Jarrige (Editor). Ruminant Nutrition. Recommended Allowances and Feed Tables. INRA. Libbey Eurotext. Paris (France), pp. 33-48

Volden H., Mydland L.T., Olaisen V., 2002. Apparent ruminal degradation and rumen escape of soluble nitrogen fractions in grass and grass silage administered intraruminally to lactating dairy cows. J. Anim. Sci. 80, 2704-2716

Waters C.I., Givens D.I., 1992. Nitrogen degradability of fresh herbage: effect of maturity and growth type, and prediction from chemical composition and by near infrared reflectance spectrometry. Anim. Feed. Sci. Tech. 38, 335-349 


\section{STRESZCZENIE}

\section{Krytyczna ocena systemów wartościowania białka dla przeżuwaczy}

Omówiono współczesne systemy oceny wartości białka na podstawie ilości aminokwasów wchłanianych w jelicie cienkim, ze szczególnym uwzględnieniem różnic koncepcyjnych i ograniczeń technicznych szacowania parametrów. Na podstawie danych z doświadczeń produkcyjnych oceniono wiarogodność różnych sposobów oceny udziału białka mikrobiologicznego w białku metabolicznym. Uwzględniono główne modele empiryczne oparte na metodzie wieloczynnikowej. Dalsze badania powinny dotyczyć modeli mechanistycznych, uwzględniających w większym stopniu interakcje w przewodzie pokarmowym i metabolizmie tkankowym. 